\title{
The first record of the introduced spider species Nesticella mogera (Yaginuma, 1972) from Russia (Aranei: Nesticidae)
}

\section{Первое дия России указание интродущированного вида пауков Nesticella mogera (Yaginuma, 1972) (Aranei: Nesticidae)}

\author{
Sergei L. Esyunin, Oksana V. Agafonova, Anastasiya A. Bykova \\ С.А. Есюнин, О.В. Агафонова, А.А. Быкова
}

Perm State University, Bukireva Street 15, Perm, 614600 Russia. E-mail: Sergei.Esyunin@psu.ru Пермский государственный университет, ул. Букирева 15, Пермь 614600 Россия.

KEY WORDS: Araneae, cave cobweb spiders, Nesticella, introduced species, synanthropic fauna, the Urals.

КЛЮЧЕВЫЕ СЛОВА: Araneae, пауки-нестициды, Nesticella, интродуцированный вид, синантропная фауна, Урал.

ABSTRACT. The introduced cave cobweb spider Nesticella mogera (Yaginuma, 1972) is recorded from greenhouses in Perm City, the Urals, being the first record of this species from Russia.

How to cite this article: Esyunin S.L., Agafonova O.V., Bykova A.A. 2019. The first record of the introduced spider species Nesticella mogera (Yaginuma, 1972) from Russia (Aranei: Nesticidae) // Arthropoda Selecta. Vol.28. No.1. P.131-134. doi: 10.15298/arthsel. 28.1.11

РЕЗЮМЕ. Интродуцированная нестицида Nesticella mogera (Yaginuma, 1972) обнаружена в теплицах города Пермь, Урал; это первое указание этого вида для России.

\section{Introduction}

At the beginning of the 20th century, only two synanthropic species were recorded from Perm Area: viz., Steatoda grossa (C.L. Koch, 1838) and Tegenaria domestica (Clerck, 1757) [Charitonov, 1925, 1926]. The third, newly introduced species - Pholcus phalangioides (Fuesslin, 1775) — was found in cargo on a barge in the river port by Charitonov [1927]. By the end of the 20th century, a list of synanthropic spider species of Perm Area had been supplemented by three more species: viz., Steatoda castanea (Clerck, 1757), Pholcus alticeps Spassky, 1932 and Sosticus loricatus (L.Koch, 1866) [Esyunin, 1995]. In the last decade, two new species of the Nesticidae have been discovered in Perm City, of which the data on Aituaria pontica (Spassky, 1932) were published Esyunin [2017]. The main aim of this paper is to provide new distributional and ecological data for Nesticella mogera (Yaginuma, 1972) which was collected from the greenhouse of the Botanical Garden of the Perm State University.

\section{Material and methods}

In October 2017, two males and a female of $N$. mogera were caught by pitfall-traps in the territory of the Perm State University during inspection of the greenhouse of the Botanical Garden. When the population of this species was re-examined in March 2018, a large number of mature and immature specimens was found, which allowed the authors to study a spatial distribution of this species and to assess some of its ecological requirements.

The greenhouse of the botanical garden of the Perm State University was built in 2010. Its plant collection is divided into five climatic/thematic compartments: "Wet Tropics", "Dry Tropics", "Subtropics", "Epiphytes", "Cacti and succulents" [Botanical Garden..., 2018]. The specimens of N. mogera were found in the first three compartments only.

The material studied here has been deposited in the Zoological Museum of the Moscow State University (ZMUM, curator: K.G. Mikhailov), the department of Invertebrate Zoology and Aquatic Ecology of the Perm State University (PSU, curator: S.L. Esyunin) and the Manchester Museum, University of Manchester, UK (MMUE, curator: D.V. Logunov).

\section{Nesticella mogera (Yaginuma, 1972)}

MATERIAL. $2 \sigma^{7} \sigma^{7}, 1+$ (PSU-7669), Russia, Perm City, Botanic Garden of the Perm State University, greenhouse, pitfalltraps, 29.IX-9.X.2017, Agafonova O.V., Bykova A.A. \& Farzalieva G.Sh. kyzy.; $10^{7}, 1$ ( $\sigma^{7} \sigma^{7}, 2$ immature $9+, 9$ juvenile specimens of different ages (MMUE), Russia, Perm City, Botanic Garden of the Perm State University, greenhouse, in litter, 14.III.2018, Esyunin S.L.

DESCRIPTION. The species has been repeatedly collected and is well-described and illustrated (e.g., Gertsch, 1973; Lehtinen, Saaristo, 1980; Marusik, Guseinov, 2003; Liu, Li, 2013); for a complete list of the taxonomic references see WSC [2018]. 
Table. Literature-derived and original data on the habitat preferences of Nesticella mogera (Yaginuma, 1972). Таблица. Литературные и оригинальные данные о биотопической приуроченности Nesticella mogera (Yaginuma, 1972).

\begin{tabular}{|c|c|c|}
\hline Region & Habitats & Literature source \\
\hline $\begin{array}{l}\text { China (Hunan, Inner } \\
\text { Mongol, Shaanxi, } \\
\text { Shandong, Zhejiang) }\end{array}$ & Sugarcane and rice fields & Yin et al. [2012] \\
\hline Guizhou Province of China & Caves & Liu, Li [2013] \\
\hline Korea & $\begin{array}{l}\text { Rice field, in ruderal vegetation of } \\
\text { agricultural, industrial and residential } \\
\text { areas }\end{array}$ & $\begin{array}{l}\text { Kim et al. [1999]; Jung et al., } 2008 \\
\text { cited in Kielhorn [2009] }\end{array}$ \\
\hline Japan & Burrows of moles & Yaginuma [1972] \\
\hline Azerbaijan & Forest litter & Marusik, Guseinov [2003] \\
\hline Hawaiian Islands & Caves & Gertsch $[1973,1984]$ \\
\hline Fiji Islands & $\begin{array}{l}\text { Bush between cultivated field and coastal } \\
\text { mangrove swamp; in jungle litter }\end{array}$ & Lehtinen, Saaristoi [1980] \\
\hline Germany & Zoo-Aquarium & Kielhorn [2009] \\
\hline England & Humid tropical greenhouse: in leaf litter & Snazell, Smithers [2007] \\
\hline Poland & $\begin{array}{l}\text { Butterfly Park: under mahogany wood } \\
\text { and large scarp bark }\end{array}$ & Bielak-Bielecki, Rozwalka [2011] \\
\hline Poland & $\begin{array}{l}\text { Garden-building hyper-market: between } \\
\text { flowerpots }\end{array}$ & Rozwalka et al. [2013] \\
\hline Hungary & $\begin{array}{l}\text { Tropical house of the Botanic Garden: in } \\
\text { leaf litter }\end{array}$ & Pfliegler [2014] \\
\hline Urals (Perm City) & $\begin{array}{l}\text { Tropical section of greenhouse: in litter } \\
\text { and micro-cavities under stones }\end{array}$ & present data \\
\hline
\end{tabular}

HABITATS AND ECOLOGICAL PREFERENCES. The primary natural habitats of $N$. mogera is unknown. In the regions of origin (see below), the species was caught both from natural habitats (caves, burrows, China, Japan; forest litter, Azerbaijan) and from anthropogenic ones (see Table). A similar habitat preference of this species was shown for the islands of the Pacific Ocean [Lehtinen, Saaristo, 1980]. In Europe and the Urals, N. mogera is a true synanthropic (=eusynanthropic) species.

On October 9th, 2017, N. mogera was discovered in the PSU's Botanical Garden for the first time. A repeated survey conducted by the authors in March 2018 revealed the viability and stability of the population of this species.

Specimens of $N$. mogera were found in the three of the five greenhouse compartments, except for its driest compartments. The largest number of specimens was found in the "Dry Tropics" compartment (Fig. 1), whereas only singletons were collected from the "Wet Tropics" and "Subtropics" compartments. In the compartment that is preferred by spiders, two climatic regimes are maintained: the summer (wet and hot) and the winter (drier and cooler). Night temperature can fall down to $+16^{\circ} \mathrm{C}$; day temperature can reach up to $+30^{\circ} \mathrm{C}$. An average temperature lies within the range +21 to $+25^{\circ} \mathrm{C}$, with the air humidity being about $80 \%$ (Sergei Shumikhin, pers. comm.).

In the "Dry Tropics" compartment, plants grow either in pots or in soil (Fig. 2). The soil surface is bare, since the leaf litter is regularly removed. Paths made of quarry tiles are laid between plants (Fig. 2) for the convenience of staff and visitors. Single specimens of $N$. mogera were found in small niches under tiles. Yet, a large population of this species was found in the garden tub, which was filled with fallen oak leaves (Fig. 3). Wet leaves were partially rotted at the tub bottom, but remained intact and dry in the upper part.
Most of the collected specimens concentrated in the lower part of the dry layer of loose leaves, on the border with the wet and densely laid litter (Fig. 4). This population consisted of males and females, immature of both sexes and juveniles.

Our observations are in agreement with Bielak-Bielecki and Rozwalka's viewpoint that $N$. mogera can be characterized as a thermophilic-hygrophilic species [Bielak-Bielecki, Rozwalka, 2011].

Historical background and modern distribution

According to Ballarin \& Li [2017], the mogera species group of the genus Nesticella was originally distributed in mainland China, separated from other species groups of the north-clade some 24 m.y.a. This hypothesis describes the continued stagnation of this group in the indigenous territory and the resettlement northward to Korea and from there eastward to Japan. The species $N$. mogera differentiated from other congeners of the mogera group at the end of the Miocene, about seven m.y.a.

Unfortunately, Marusik's hypothesis about the ancient Caucasian-Far East disjunctive range of $N$. mogera [Marusik, Guseinov, 2003] was not discussed by Ballarin \& Li [2017]. Yet, the disjunctive type of species distribution is not unique. Numerous examples of the similar ranges in spiders from different families were summarized by Marusik et al. [2004]. It should be noticed though that in the Caucasus the $N$. mogera was collected from "the litter at the edge of relic Lenkoran 


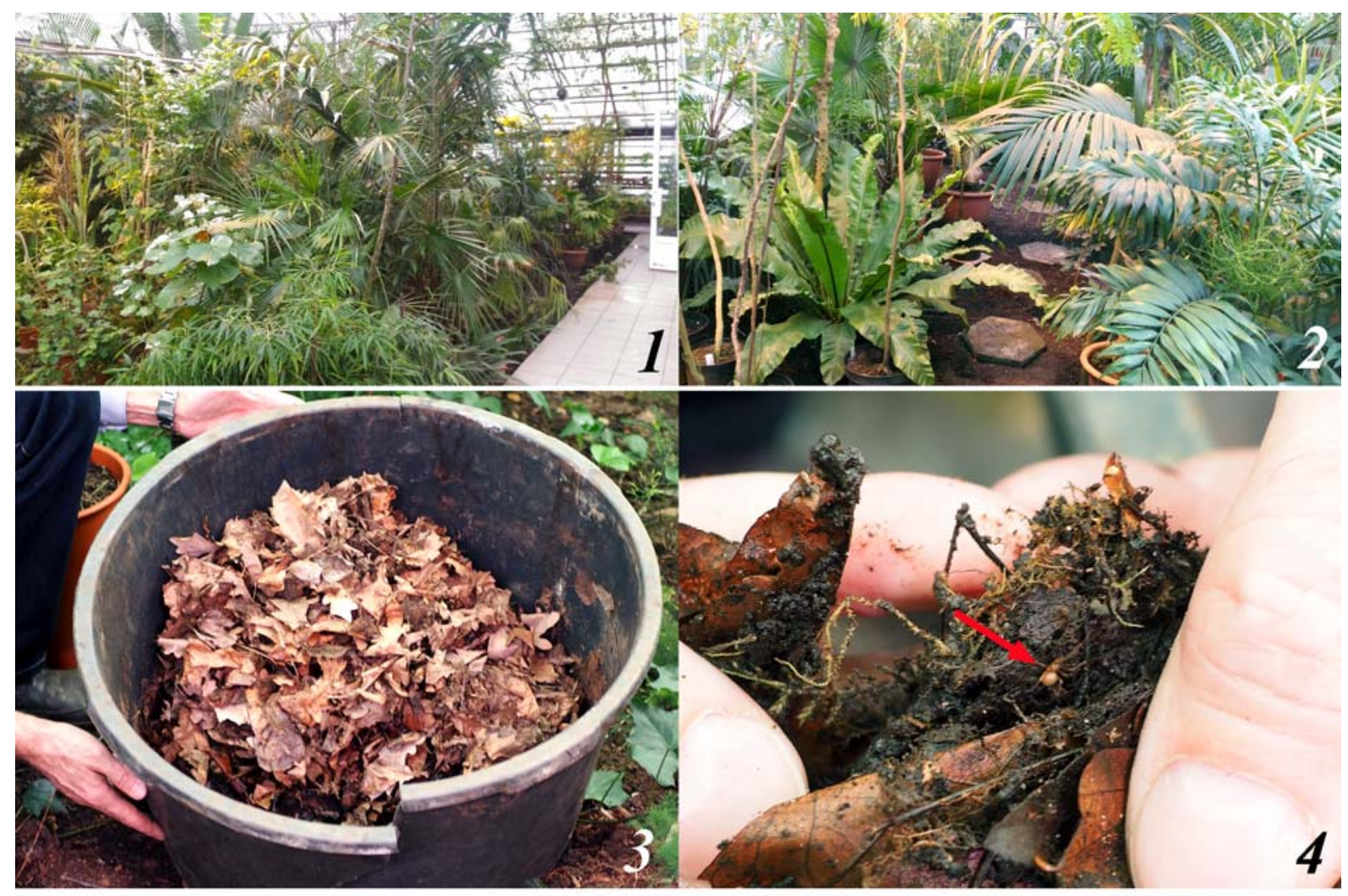

Figs 1-4. A general view of the "Dry Tropics" compartment of the greenhouse in the Botanical Garden of the Perm State University and the habitat of Nesticella mogera (Yaginuma, 1972): 1, 2 - planted plants and soil surface; 3 - garden tub with leaf litter; 4 - the female of $N$. mogera on moist litter.

Рис. 1-4. Общий вид отдела “Сухие тропики” оранжереи Ботанического сада Пермского университета и местообитание Nesticella mogera (Yaginuma, 1972): 1,2 - посаженные растения и поверхность почвы; 3 — садовая кадка с листовой подстилкой; 4 - самка N. mogera на сырой подстилке.

forest" [Marusik, Guseinov, 2003: 38]. The time of species differentiation in the mogera species group coincided with the time of biota change in Europe and the Caucasus. According to viewpoints of Soviet botanists (e.g., Kleopov, 1990), the "Turgai" flora of Europe and the Caucasus was formed under a strong influence of the East Asian genetic center. Migrations of the biota from the east to the west could go both through "northern" plains and through "southern" mountain routes. Southern migration flows passed through the "southern mountain path across Central China Ridges, Kunlun, TienShan and Pamir-Altai (translated by S.E.)" [Kleopov, 1990: 253]. Thus, according to the latter hypothesis, the Caucasian population of $N$. mogera could be allochthonous, originating from mainland China.

Thus, before the human impact, the species' historical natural range consisted of two parts. The first part covered the territory of China (Hunan, Inner Mongolia, Shaanxi, Shandong, Zhejiang, Guizhou) [Yin et al., 2012; Liu, Li, 2013], Korea [Kim et al., 1999; Jung et al., 2008] and Japan [Yaginuma 1972], the second one - the Lankaran Lowland in the Caucasus [Marusik, Guseinov, 2003].

Despite the fact that the "vast majority of modern Nesticella are essentially troglophilic organisms" [Bal- larin, Li, 2017: 587], N. mogera has preserved an ancient epigean lifestyle. Perhaps, this fact contributed to its modern expansion, unique "among all the nesticids" [Marusik, Guseinov, 2003: 38]. In the 20th century, the species was introduced to the Hawaiian [Gertsch, 1973, 1984] and Fiji [Lehtinen, Saaristoi, 1980] Islands, whereas in the 21 st century to Europe (England; Germany; Poland, Hungry) [Snazell, Smithers, 2007; Kielhorn, 2009; Bielak-Bielecki, Rozwalka, 2011; Rozwalka et al., 2013; Pfliegler, 2014].

The Urals population is likely to be of the Caucasian origin. The Botanical Garden of the Perm State University actively interacts with European botanical gardens. However, only plant seeds are imported from European centers (Sergei Shumikhin, pers. comm.). Yet, living plants along with the soil have been imported from various botanical gardens on the Black Sea coast many times. Most likely, the $N$. mogera was introduced into the greenhouse with tropical plants originated from the "White Nights", the Subtropical Botanical Garden of the Kuban, in March 2017. Earlier, in 2013 , lots of tropical plants were imported from the Sukhumi Botanical Garden, Abkhazia (Sergei Shumikhin, pers. comm.). 
Acknowledgments. We are grateful to Sergei Shumikhin, the Director of the Botanical Garden of the Perm State University, for the opportunity to work in the garden and for the provided information. Special thanks go to Dmitri V. Logunov (Manchester, UK) for commenting on the manuscript and editing the English of the final draft.

\section{References}

Ballarin F., Li S. 2017. Diversification in tropics and subtropics following the midMiocene climate change: A case study of the spider genus Nesticella // Global Change Biology. Vol.24. P.577-591.

Bielak-Bielecki P., Rozwalka R. 2011. Nesticella mogera (Yaginuma, 1972) (Araneae: Nesticidae) in Poland // Zeszyty Naukowe Uniwersytetu Szczecińskiego, Acta Biologica. Vol.18. No.676. P.137-141.

[Botanical Garden of the Perm State University]. 2018. Available at http://wsc.nmbe.ch http://www.psu.ru/podrazdeleniya/podrazdeleniya-obespecheniya/botanicheskij-sad (accessed 3 July 2018) [in Russian].

Charitonov D.E. 1925. [Materials on the spider fauna of the Perm Gouvernement] // Ezhegodnik Zoologicheskogo Muzeya AN SSSR. P.103-136 [in Russian].

Charitonov D.E. 1926. [Materials on the spider fauna of the Cherdyn Area] // Izvestiya biologicheskogo nauchno-issledovatelskogo instituta pri Permskom universitete. Vol.4. No.6. P.257273 [in Russian].

Charitonov D.E. 1927. Arachnologica varia, I, II // Izvestiya biologicheskogo nauchno-issledovatelskogo instituta i biologicheskoy stantsii pri Permskom universitete. Vol.5. No.5. P.219226 [in Russian].

Esyunin S.L. 1995. [Fauna of spiders of living quarters of Perm City] // Ekologiya i okhrana okruzhayuschey sredy. Part 3. Perm. P.13 [in Russian].

Esyunin S.L. 2017. New data on Aituaria pontica (Spassky, 1932) (Aranei: Nesticidae) // Arthropoda Selecta. Vol.26. No.3. P. 241-243.

Gertsch, W.J. 1973. The cavernicolous fauna of Hawaiian lava tubes, 3. Araneae (spiders) // Pacific Insects. Vol.15. No.1. P.163-180.

Gertsch W.J. 1984. The spider family Nesticidae (Araneae) in North America, Central America, and the West Indies // Bulletin of the Texas Memorial Museum. No.31. P.1-91.

Jung M.-P., Kim S.-T., Kim H., Lee J.-H. 2008. Biodiversity and community structure of ground-dwelling spiders in four differ- ent field margin types of agricultural landscapes in Korea // Applied soil ecology. Vol.38. No.2. P.185-195.

Kielhorn K.-H. 2009. First records of Spermophora kerinci, Nesticella mogera and Pseudanapis aloha on the European mainland (Araneae: Pholcidae, Nesticidae, Anapidae) // Arachnologische Mitteilungen. Bd.37. S.31-34.

Kim J.P., Yoo Y.S., Lee Y.B. 1999. A newly recorded species of the genus Nesticella (Aranea, Nesticidae) in Korea // Korean Journal of Systematic Zoology. Vol.15. No.2. P.183-187.

Kleopov Yu.D. 1990. [Analysis of the flora of broadleaved forests of the USSR European part]. Kiev: Naukova Dumka. 352 p. [In Russian]

Lehtinen P.T., Saaristo M.I. 1980. Spiders of the Oriental-Australian region. II. Nesticidae // Annales Zoologici Fennici. Vol.17. P.47-66.

Liu J., Li S.Q. 2013. New cave-dwelling spiders of the family Nesticidae (Arachnida, Araneae) from China // Zootaxa. Vol.3613. P.501-547.

Marusik Yu.M., Guseinov E.F. 2003. Spiders (Arachnida: Aranei) of Azerbaijan. 1. New family and genus records // Arthropoda Selecta. Vol.12. No. 1. P.29-46.

Marusik Yu.M., Guseinov E.F., Koponen S., Yoshida H. 2004. A new case of Caucasus-Far East disjunctive range in spiders (Araneae) // Acta arachnologica. Vol.53. No.2. P.125-129.

Pfliegler W.P. 2014. Records of some rare and interesting spider (Araneae) species from anthropogenic habitats in Debrecen, Hungary // e-Acta Naturalia Pannonica. Vol.7. P.143-156.

Rozwalka R., Rutkowski T., Bielak-Bielecki P. 2013. New data on introduced and rare synanthropic spider species (Arachnida: Araneae) in Poland // Annales Universitatis Mariae CurieSklodowska, Lublin-Polonia, Section C. Vol.68, No.1. P.127150 .

Snazell R., Smithers P. 2007. Pseudanapis aloha Forster (Araneae, Anapidae) from the Eden Project in Cornwall, England // Bulletin of the British Arachnological Society. Vol.14. Pt.2. P.7476.

Yaginuma T. 1972. Revision of the short-legged nesticid spiders of Japan // Bulletin of the National Museum of Nature and Science Tokyo. Vol.15. P.619-622.

Yin C.M., Peng X.J., Yan H.M., Bao Y.H., Xu X., Tang G., Zhou Q.S., Liu P. 2012. Fauna Hunan: Araneae in Hunan, China. Changsha: Hunan Science and Technology Press. 1590 p.

WSC 2018. World Spider Catalog. Version 19.5. Natural History Museum Bern. Available at http://wsc.nmbe.ch (accessed 17 July 2018).

Responsible editor D.V. Logunov 